\title{
Understanding online shopping adoption: The unified theory of acceptance and the use of technology with perceived risk in millennial consumers context
}

\author{
Rian Piarna $^{1 *}$, Ferdi Fathurohman ${ }^{2}$, Nunu Nugraha ${ }^{3}$ \\ ${ }^{1}$ Department of Information Management, Subang State Polytechnic, Subang, Indonesia \\ ${ }^{2}$ Department of Agroindustry, Subang State Polytechnic, Subang, Indonesia \\ ${ }^{3}$ Department of Information Management, Subang State Polytechnic, Subang, Indonesia \\ *Corresponding Author(s) Email: piarna@ polsub.ac.id
}

\begin{abstract}
Online shopping is growing so rapidly and has attracted millennials in various way. Unfortunately, the discussion regarding the adoption of online shopping in millennial consumers' context with perceived risk application was still limited. Therefore, the purpose of this study was to investigate the effect of performance expectancy, expectation efforts, social influence, facilitation conditions, hedonic motivation, price value, habits, and perceived risks on behavioral intentions and use behavior. This study also discusses the effect of perceived risks on financial risk, performance risk, and privacy risk. This study can be classified as explanatory research with purposive sampling and partial least square as sampling techniques and data analysis. This study was designed to focus on individuals who can be classified as an online shopper with a range of age of 18-35 years old. The results show that the millennial generation is influenced by the social environment and habits in shaping their behavioral intention. Millennial consumers are also proving very concerned about their perceived risk of financial, performance, and privacy issues when doing online shopping. Interestingly, six of the factors studied (performance expectancy, effort expectancy, facilitating conditions, hedonic motivation, price value, and perceived risk) do not have any influence on the intention to use online commerce technology.
\end{abstract}

Keywords: UTAUT 2; Perceived Risk; Online Shopping; Adoption; Behavioral Intention; Use Behavior

JEL Code:

M31, M37

DOI:

10.31106/jema.v17i1.5050

Article History:

Received 2020-01-13

Reviewed 2020-01-18

Revised 2020-01-21

Accepted 2020-01-28

Licensed:

CC-BY 
Understanding online shopping adoption: The unified theory of acceptance and the use of technology in millennial consumers context and perceived risk application by Rian Piarna, Ferdi Fathurohman, Nunu Nugraha

\section{Introduction}

The availability of the internet on computers and mobile devices is increasing the growth of e-commerce markets throughout the world. Consumers can more easily access various products from several vendors at any time by shopping online (Hurtado et al., 2019). Today's internet users in Indonesia are mostly carried out by millennials. Millennial consumers are an important issue in the development of the digital world and social media is a communication space for this generation (Khechine et al., 2020). This condition underlies the selection of millennial consumers as the object of this research in adopting e-commerce using the Unified Theory of Acceptance method and Use of Technology in Consumer Context (UTAUT2). UTAUT2 is the development of the UTAUT model concept (Venkatesh et al., 2012). UTAUT2 illustrates how consumers adapt to technology. Millennial consumers also concerned about risk perception in deciding whether they should purchase online or not (Wang \& Herrando, 2019). Lestari (2019) and Amrullah \& Priyono (2018) even added that perceived risks have a positive effect on attitudes and intentions to adopt e-commerce. Previous research has provided limited understanding regarding the adoption of online shopping in millennial consumers' context with perceived risk application. Therefore, the purpose of this study was to investigate the effect of performance expectancy, expectation efforts, social influence, facilitation conditions, hedonic motivation, price value, habits, and perceived risks on behavioral intentions and use behavior. This study also discusses the effect of perceived risks on financial risk, performance risk, and privacy risk.

\section{Literature Review}

\section{Unified Theory of Acceptance and Use of Technology (UTAUT)}

UTAUT has been widely used models to predict behavioral intention. Celik (2016) stated that the UTAUT model proved a robust and valid model in the online shopping context which means that the model can be used to explain the degree of purchase intention and actual purchase. Cimperman et al. (2016) defined UTAUT as "a measure of the strength of one's intention to perform a specified behavior." The UTAUT model argues that an individual adoption on new technology mainly influenced by four factors which is performance expectancy (PE), effort expectancy (EE), social influence (SI), and facilitating conditions (FC). Most studied about UTAUT was focus only on a subset of the model (Venkatesh et al., 2012) and not have utilized moderators like age, experience, and gender because it may not be any variation in the moderator for the adoption (Dwivedi et al., 2019). 
Madigan et al, (2016) defined performance expectancy (PE) as the degree of individual belief that using technology (internet) will help him or her to attain gains in their shopping activities. Consumers perceived that using the internet for shopping will provide benefits and help them saving time, money, effort, and gain service effectiveness (Venkatesh et al., 2012). Effort expectancy (EE) defined as the level of convenience associated with internet usage (Liu et al., 2018). It means that if consumers found that the use of the internet for online shopping is easy and does not require any effort, the possibility of online shopping adoption will be higher. Previous studies from Venkatesh et al. (2012), Kabra et al. (2017), Jewer (2018) found that there is a significant relationship between performance expectancy and effort expectancy on behavioral intention. Therefore, the proposed hypotheses in this study can be described as follow.

$\mathrm{H}_{1}$ : $\quad$ Performance expectancy (PE) significantly affect behavioral intention (BI)

$\mathrm{H}_{2}$ : Effort expectancy (EE) significantly affect behavioral intention (BI)

Venkatesh et al. (2012) defined social influence (SI) as the effect of environmental factors such as the opinions of relatives, friends, and superiors on user behavior with subjective norms. (Tarhini et al., 2016) added that social influences may refer to the social pressure from the external environment which may affect their perceptions and behaviors of engaging in specific actions. Therefore, when they perceived online shopping positively, it can encourage consumers to adopt the use of the internet for online shopping. (Venkatesh et al., 2003) has been defined facilitating conditions (FC) as "the degree to which an individual believes that an organizational and technical infrastructure exists to support the use of the system" including knowledge, capabilities, and consumer resources (Venkatesh et al., 2012). If internet infrastructure and knowledge that needed in using the internet available, also there is support from social for using the internet, the intended behavior to adopt the internet for online shopping will be increased. Previous studies from Venkatesh et al. (2003), Diño \& de Guzman (2015) concluded that there is a significant relationship between social influences and facilitating conditions on behavioral intention. Facilitating conditions also prove significantly affects actual usage behavior (Zuiderwijk et al., 2015).

$\mathrm{H}_{3}$ : Social influence (SI) significantly affect behavioral intention (BI)

$\mathrm{H}_{4 \mathrm{a}}$ : Facilitating condition (FC) significantly affect behavioral intention (BI)

$\mathrm{H}_{4 b}$ : Facilitating condition (FC) significantly affect use behavior (UB)

Behavioral intention (BI) reflects the extent to which customers are likely to use technology (Venkatesh et al., 2012). Behavior intention is the most powerful determining factor in individual behavior towards technology acceptance (Alalwan et al., 2018). 
Understanding online shopping adoption: The unified theory of acceptance and the use of technology in millennial consumers context and perceived risk application by Rian Piarna, Ferdi Fathurohman, Nunu Nugraha

$\mathrm{H}_{5}: \quad$ Behavioral intention (BI) significantly affect use behavior (UB)

\section{Hedonic Motivation, Price Value, and Habit}

Venkatesh et al. (2012) and Tak \& Panwar (2017) stated that to be more adaptive to consumer use framework, the original UTAUT model has been extended to UTAUT 2 which added three new constructs namely hedonic motivation, price value, and habit. While hedonic motivation (HM) defined as $\mathrm{s}$ the "fun or pleasure derived from using a technology" by (Venkatesh et al., 2012). Price value (PV) and habit (H) can be defined as "consumers' cognitive tradeoff between the perceived benefits of the applications and the monetary cost for using them" and s "the extent to which people tend to perform behaviors automatically because of learning" (Herrero et al., 2017). Previous studies from (Alalwan et al., 2017), (Herrero et al., 2017), and (Wong et al., 2020) found that behavioral intention was significantly influenced by hedonic motivation, price value, and habit. Not only influences behavioral intentions, (Gupta \& Dogra, 2017) also found the significant contribution of habit on actual usage behavior.

$\mathrm{H}_{6}$ : Hedonic motivation (HM) significantly affect behavioral intention (BI)

$\mathrm{H}_{7}$ : Price value (PV) significantly affect behavioral intention (BI)

$\mathrm{H}_{8 \mathrm{a}}$ : Habit (H) significantly affect behavioral intention (BI)

$\mathrm{H}_{8 \mathrm{~b}}$ : Habit (H) significantly affect use behavior (UB)

\section{Perceived Risk}

Farivar et al. (2018) defined perceived risk as users' beliefs about potential negative consequences or the uncertainty of outcome or consequences (Buehler \& Maas, 2018) of an online transaction with a specific website. Featherman \& Pavlou (2003) added that perceived risk plays an important role as an inhibitor online purchase decision. A study from (Indiani et al., 2015) and (Zulfikar \& Mayvita, 2018) even concluded that perceived risk has a stronger impact on an actual purchase than trust. Perceived risk itself can be divided into three categories namely financial risk, performance risk, and privacy risk. While financial risk (FR) is a potential monetary loss that will be experienced by consumers when shopping online (Salam et al., 2003). Han \& Kim (2017) defined performance risk (PFMR) as the risk caused by electronic services (shopping websites) whose performance does not meet consumer expectations. Warkentin et al. (2002) added that privacy risk (PVR) can be defined as the expected losses control of their personal information that caused by their online shopping activities or identity theft (Han \& Kim, 2017). These three risks that are felt by consumers are 
second-order factors that influence the intention to use the internet to shop online. Thus, the lower degree of perceived risk will impact the higher possibility of the adoption of online shopping (Choi et al., 2013; Tingchi Liu et al., 2013).

$\mathrm{H}_{9 \mathrm{a}}$ : There is a significant influence of perceived risk (PR) on financial risk (FR)

$\mathrm{H}_{9 b}$ : There is a significant influence of perceived risk (PR) on performance risk (PFMR)

$\mathrm{H}_{9 \mathrm{c}}$ : There is a significant influence of perceived risk (PR) on privacy risk (PVR)

$\mathrm{H}_{10}$ : There is a significant influence of perceived risk (PR) on behavioral intention (BI)

\section{Methods}

Figure 1. Research Framework

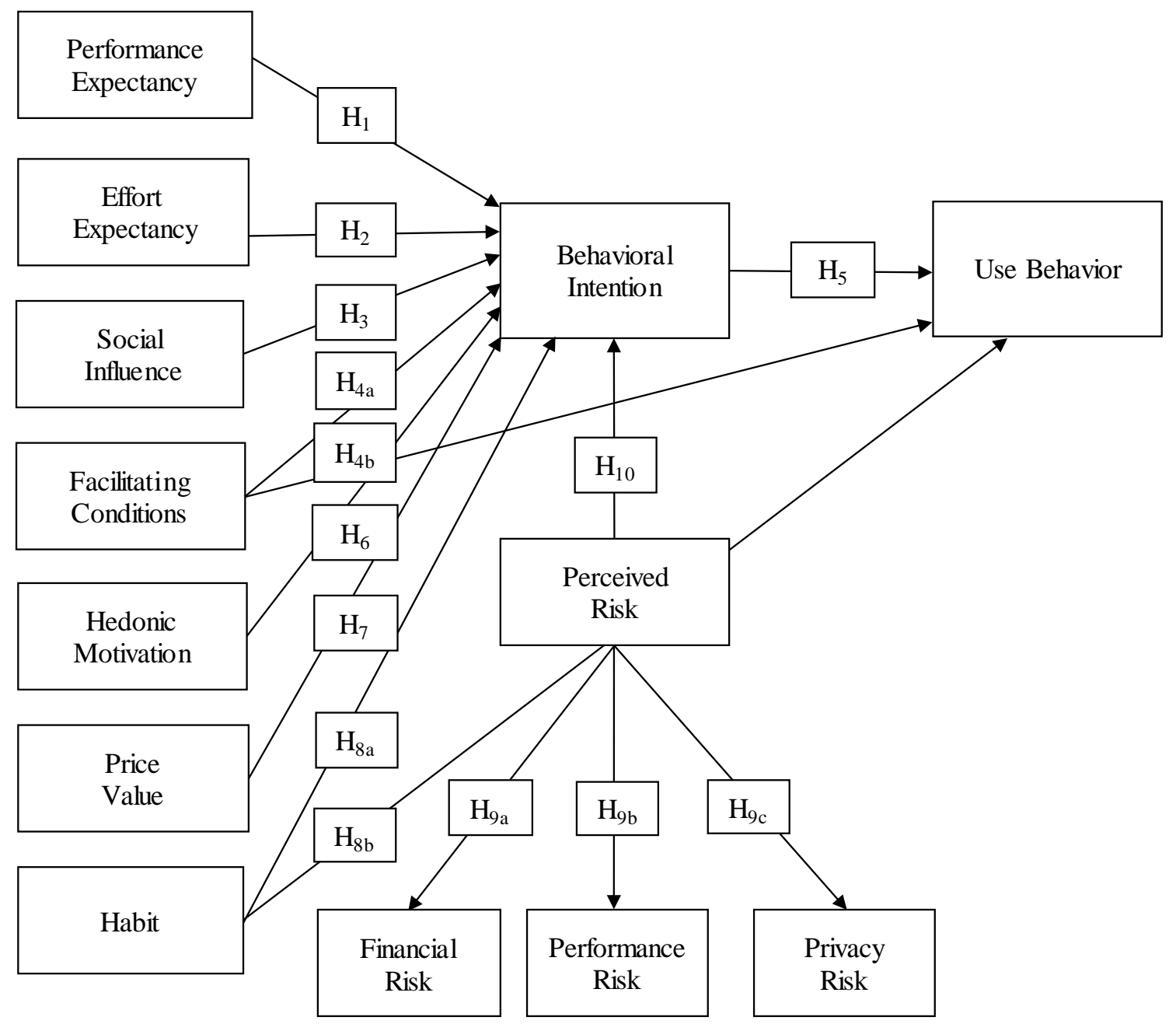

This study can be classified as explanatory research. Purposive sampling and partial least square used as sampling techniques and data analysis. This study was designed to focus on individuals who can be classified as an online shopper with a range of age of 18-35 years old. The rules for taking a minimum number of samples in PLS-SEM are two conditions; the first is based on ten times the number of formative indicators and secondly, it is based on ten 
Understanding online shopping adoption: The unified theory of acceptance and the use of technology in millennial consumers context and perceived risk application by Rian Piarna, Ferdi Fathurohman, Nunu Nugraha

times the number of lines (paths) connecting each latent variable in the study (Helm, 2005). Therefore, the number of collected samples in this study were 150 samples.

Table 1. Validity and Reliability Test

\begin{tabular}{|c|c|c|c|c|c|c|c|}
\hline Variable & $\begin{array}{c}\text { Outer } \\
\text { Loadings }\end{array}$ & $\begin{array}{l}\text { Composite } \\
\text { Reliability }\end{array}$ & AVE & Variable & $\begin{array}{c}\text { Outer } \\
\text { Loadings }\end{array}$ & $\begin{array}{l}\text { Composite } \\
\text { Reliability }\end{array}$ & AVE \\
\hline PE1 & 0.827 & & & PR1 & 0.791 & 0.911 & 0.596 \\
\hline PE2 & 0.826 & 0.875 & 0.700 & PR2 & 0.878 & & \\
\hline PE3 & 0.857 & & & PR3 & 0.910 & & \\
\hline EE1 & 0.892 & & & PFMR1 & 0.828 & 0.892 & 0.734 \\
\hline EE2 & 0.930 & 0.941 & 0.841 & PFMR2 & 0.856 & & \\
\hline EE3 & 0.928 & & & PFMR3 & 0.885 & & \\
\hline SI1 & 0.851 & & & FR1 & 0.832 & 0.815 & 0.688 \\
\hline SI2 & 0.911 & 0.915 & 0.782 & FR2 & 0.826 & & \\
\hline SI3 & 0.890 & & & PVR1 & 0.899 & 0.934 & 0.826 \\
\hline $\mathrm{FC} 1$ & 0.839 & & & PVR2 & 0.945 & & \\
\hline FC2 & 0.893 & 0.899 & 0.748 & PVR3 & 0.881 & & \\
\hline FC3 & 0.862 & & & BI1 & 0.807 & 0.908 & 0.711 \\
\hline HM1 & 0.936 & & & $\mathrm{BI} 2$ & 0.863 & & \\
\hline HM2 & 0.909 & 0.940 & 0.840 & $\mathrm{BI} 3$ & 0.877 & & \\
\hline HM3 & 0.904 & & & BI4 & 0.824 & & \\
\hline PV1 & 0.902 & & & UB1 & 0.896 & 0.925 & 0.805 \\
\hline PV2 & 0.869 & 0.916 & 0.784 & UB2 & 0.886 & & \\
\hline PV3 & 0.885 & & & UB3 & 0.909 & & \\
\hline $\mathrm{H} 1$ & 0.874 & & & & & & \\
\hline $\mathrm{H} 2$ & 0.917 & 0.928 & 0.812 & & & & \\
\hline H3 & 0.912 & & & & & & \\
\hline
\end{tabular}

This study used Venkatesh et al. (2012) and Featherman \& Pavlou (2003) items to measures each latent variable (Appendix 1a, 1b). Model measurements are used to evaluate data in determining the validity and reliability of data. The construct relationship with each indicator of this study is a reflective measurement model. In the measurement of reflective models, there are two tests of validity, namely convergent validity testing and discriminant validity testing (Primanto, 2019). Test of convergent validity in the evaluation of the 
measurement model is obtained through the factor loading (outer loadings), composite reliability that should greater than 0.700 , and the minimum value of average variance extracted (AVE) parameter that should reach 0.500. Table 1 shows that the model is valid and reliable due to the value of outer loading and composite reliability that greater than 0.70 with the result of AVE is above the existing standard.

\section{Result and Discussion}

Table 2. Partial Least Square Result

\begin{tabular}{lccccc}
\hline Correlation & P-Value & t-Value & t-Statistic & Result & Decision \\
\hline PE -> BI & 0.971 & 0.036 & 1.976 & t-Value $<$ t-Statistic & $\mathrm{H}_{1}$ Rejected \\
EE -> BI & 0.317 & 1.004 & 1.976 & t-Value $<$ t-Statistic & $\mathrm{H}_{2}$ Rejected \\
SI -> BI & 0.043 & 2.045 & 1.976 & t-Value $>$ t-Statistic & $\mathrm{H}_{3}$ Accepted \\
FC -> BI & 0.332 & 0.974 & 1.976 & t-Value $<$ t-Statistic & $\mathrm{H}_{4 \mathrm{a}}$ Rejected \\
FC-> UB & 0.034 & 2.141 & 1.976 & t-Value $>$ t-Statistic & $\mathrm{H}_{4 b}$ Accepted \\
BI -> UB & 0.000 & 5.157 & 1.976 & t-Value $>$ t-Statistic & $\mathrm{H}_{5}$ Accepted \\
HM -> BI & 0.377 & 0.886 & 1.976 & t-Value $<$ t-Statistic & $\mathrm{H}_{6}$ Rejected \\
PV -> BI & 0.078 & 1.773 & 1.976 & t-Value $<$ t-Statistic & $\mathrm{H}_{7}$ Rejected \\
H -> BI & 0.000 & 8.626 & 1.976 & t-Value $>$ t-Statistic & $\mathrm{H}_{8 \mathrm{a}}$ Accepted \\
H-> UB & 0.018 & 2.388 & 1.976 & t-Value $>$ t-Statistic & $\mathrm{H}_{8 b}$ Accepted \\
PR -> FR & 0.000 & 29.167 & 1.976 & t-Value $>$ t-Statistic & $\mathrm{H}_{9 \mathrm{a}}$ Accepted \\
PR -> PFMR & 0.000 & 18.672 & 1.976 & t-Value $>$ t-Statistic & $\mathrm{H}_{9 b}$ Accepted \\
PR -> PVR & 0.000 & 61.547 & 1.976 & t-Value $>$ t-Statistic & $\mathrm{H}_{9 \mathrm{c}}$ Accepted \\
PR -> BI & 0.146 & 1.460 & 1.976 & t-Value $<\mathrm{t}$-Statistic & $\mathrm{H}_{10}$ Rejected \\
\hline
\end{tabular}

This study proved the direct relationship of the proposed hypotheses of $\mathrm{H}_{3}, \mathrm{H}_{4 b}, \mathrm{H}_{5}, \mathrm{H}_{8 \mathrm{a}}$, $\mathrm{H}_{8 \mathrm{~b}}, \mathrm{H}_{9 \mathrm{a}}, \mathrm{H}_{9 \mathrm{~b}}, \mathrm{H}_{9 \mathrm{c}}$. The $\mathrm{t}$-value of that direct relationship was greater than t-statistic which means that all the proposed hypotheses mentioned above were accepted. This study supports a part of the conclusion of previous studies from Venkatesh et al. (2003), Venkatesh et al. (2012), Diño \& de Guzman (2015), Kabra et al. (2017), Jewer (2018) who stated there is a significant relationship between social influences, and behavioral intention (adopting online shopping). This study also successfully prove Gupta \& Dogra (2017) and Alalwan et al. (2018) argument that stated that there is a significant relationship between habit, behavioral intention, and use behavior. Similar to the result of Kim \& Zhang (2016), Choi et al. (2013) and Tingchi Liu et al. (2013) study, financial risk, performance risk, and privacy risk 
Understanding online shopping adoption: The unified theory of acceptance and the use of technology in millennial consumers context and perceived risk application by Rian Piarna, Ferdi Fathurohman, Nunu Nugraha

significantly proved to affect perceived risk in this study. Our study revealed that respondents in this study were largely influenced by the endorsement of their peer group (family and friend) in deciding whether they should try online shopping or not. They also have all technology and human resources (like mobile devices, internet, know-how to utilize the internet, also supportive peer groups) which make them more confident to make an actual purchase (not only limited on behavioral intention) through the online channel. The majority of respondents in this study also can be classified as tech-savvy, a technology geek that familiar with the use of the internet and always up-to-date with the technology they use (Narasuman et al., 2011). Therefore, as the usage of the internet become a habit on the millennial generation, it appears that habit will automatically guide future behavior in using the internet to purchase products. Ouellette \& Wood (1998) concluded that there is a significant direct effect between past behavior and intention on future behavior. Millennial customers also prove very concerned about their perceived risk of financial, performance, and privacy issues when doing online shopping in this study.

Meanwhile, this study failed to prove the direct relationship of the proposed hypotheses of $\mathrm{H}_{1}, \mathrm{H}_{2}, \mathrm{H}_{4 a}, \mathrm{H}_{6}, \mathrm{H}_{7}, \mathrm{H}_{10}$. The t-value of that direct relationship was lower than t-statistic which means that all the proposed hypotheses mentioned above were rejected. Although this study failed to supports the conclusion of previous studies from Venkatesh et al. (2003), Venkatesh et al. (2012), Diño \& de Guzman (2015), Kabra et al. (2017), Jewer (2018), the result of this study is similar with Siddique (2012), Jambulingam (2013), Sahu \& Singh (2017), Herrero et al. (2017), Somba et al. (2018) finding which concluded that performance expectancy, effort expectancy, facilitating conditions, hedonic motivations, and price value had no significant effect on behavioral intention. Nowadays, millennial believes that the internet is easy to access and provide a better experience. Thus, completing an online transaction is no longer becoming an issue in online commerce (Yu \& Chen, 2018). As a result of that, performance expectancy, effort expectancy, and facilitating conditions is no longer a determining factor that would influence behavioral intention as it used to.

This study also concluded that the adoption and the use of technology (online commerce) were not influenced by hedonic motivation and price value. Pham et al. (2018) and Kapferer et al. (2014) argue that an individual with hedonic personality will tend to see the pleasure, joyfulness, luxurious, and exclusive experiences that brand offers first. They are not looking for a new technology of online shopping that affordable only, they are looking for technology that can give them pleasures, exclusivity, and enhances their satisfaction. Octaviani \& 
Gunawan (2018) and Octarina et al. (2019) added that the high level of risk perceptions that consumers feel does not affect the intention of consumers to buy a product online which means that perceived risk had no significant effect on behavioral intention. (Primanto et al. (2018) argues that the good reputation of the online marketplace is enough to make consumer believes in making a purchase decision. Therefore, consumers perceived risk will be lower when the marketplace vendor is more well-know.

\section{Conclusion and Suggestion}

The results of this study indicate that the millennial generation is influenced by the social environment and habits in shaping their behavioral intention. It means that respondents in this study were largely influenced by the endorsement of their peer group (family and friend) and as the usage of the internet becomes a habit on the millennial generation, it appears that habit will automatically guide future behavior in using the internet to purchase products. Millennial consumers are also proving very concerned about their perceived risk of financial, performance, and privacy issues when doing online shopping. They also believe that the internet is easy to access and provide a better experience. Therefore, performance expectancy, effort expectancy, and facilitating conditions are no longer a determining factor that would influence behavioral intention as it used to. Regarding the absence effect of hedonic motivation, price value, perceived risk on the adoption and the use of online commerce technology it indicates that they are looking for online commerce technology that can give them measurement, exclusivity, and enhances their satisfaction not just affordable. They also believe that the well-known reputation of an online marketplace is enough to make them purchasing through online channels.

\section{References}

Alalwan, A. A., Dwivedi, Y. K., \& Rana, N. P. (2017). Factors influencing adoption of mobile banking by Jordanian bank customers: Extending UTAUT2 with trust. International Journal of Information Management, 37(3), 99-110. https://doi.org/10.1016/j.ijinfomgt.2017.01.002

Alalwan, A. A., Dwivedi, Y. K., Rana, N. P., \& Algharabat, R. (2018). Examining factors influencing Jordanian customers' intentions and adoption of internet banking: Extending UTAUT2 with risk. Journal of Retailing and Consumer Services, 40, 125-138. https://doi.org/10.1016/j.jretconser.2017.08.026

Amrullah, A., \& Priyono, A. (2018). Integrasi aspek risiko dalam model unified theory of 
Understanding online shopping adoption: The unified theory of acceptance and the use of technology in millennial consumers context and perceived risk application by Rian Piarna, Ferdi Fathurohman, Nunu Nugraha

acceptance and usage of technology untuk menganalisis penerimaan teknologi go-ride. MIX: Jurnal Ilmiah Manajemen, 8(1), 33. https://doi.org/10.22441/mix.2018.v8i1.003

Buehler, P., \& Maas, P. (2018). Consumer empowerment in insurance. International Journal of Bank Marketing, 36(6), 1073-1097. https://doi.org/10.1108/IJBM-12-2016-0182

Celik, H. (2016). Customer online shopping anxiety within the unified theory of acceptance and use technology (UTAUT) framework. Asia Pacific Journal of Marketing and Logistics, 28(2). https://doi.org/10.1108/APJML-05-2015-0077

Choi, J., Lee, A., \& Ok, C. (2013). The effects of consumers' perceived risk and benefit on attitude and behavioral intention: A study of street food. Journal of Travel and Tourism Marketing, 30(3), 222-237. https://doi.org/10.1080/10548408.2013.774916

Cimperman, M., Makovec Brenčič, M., \& Trkman, P. (2016). Analyzing older users' home telehealth services acceptance behavior-applying an extended UTAUT model. International Journal of Medical Informatics, 90, 22-31. https://doi.org/10.1016/j.ijmedinf.2016.03.002

Diño, M. J. S., \& de Guzman, A. B. (2015). Using partial least squares (PLS) in predicting behavioral intention for telehealth use among filipino elderly. Educational Gerontology, 41(1), 53-68. https://doi.org/10.1080/03601277.2014.917236

Dwivedi, Y. K., Rana, N. P., Jeyaraj, A., Clement, M., \& Williams, M. D. (2019). Reexamining the unified theory of acceptance and use of technology (UTAUT): towards a revised theoretical model. Information Systems Frontiers, 21(3), 719-734. https://doi.org/10.1007/s10796-017-9774-y

Farivar, S., Turel, O., \& Yuan, Y. (2018). Skewing users' rational risk considerations in social commerce: An empirical examination of the role of social identification. Information and Management, $\quad$ 55(8), https://doi.org/10.1016/j.im.2018.05.008

Featherman, M. S., \& Pavlou, P. A. (2003). Predicting e-services adoption: A perceived risk facets perspective. International Journal of Human Computer Studies, 59(4), 451-474. https://doi.org/10.1016/S1071-5819(03)00111-3

Gupta, A., \& Dogra, N. (2017). Tourist adoption of mapping apps: a UTAUT 2 perspective of smart travellers. Tourism and Hospitality Management, 23(2), 145-161. 
https://doi.org/10.20867/thm.23.2.6

Han, M. C., \& Kim, Y. (2017). Why consumers hesitate to shop online: perceived risk and product involvement on Taobao.com. Journal of Promotion Management, 23(1), 24-44. https://doi.org/10.1080/10496491.2016.1251530

Helm, S. (2005). Designing a formative measure for corporate reputation. Corporate Reputation Review, 8(2), 95-109. https://doi.org/10.1057/palgrave.crr.1540242

Herrero, Á., San Martín, H., \& Garcia-De los Salmones, M. del M. (2017). Explaining the adoption of social networks sites for sharing user-generated content: A revision of the UTAUT2. Computers in Human Behavior, 71, 209-217. https://doi.org/10.1016/j.chb.2017.02.007

Hurtado, P. A., Dorneles, C., \& Frazzon, E. (2019). Big data application for e-commerce's logistics: A research assessment and conceptual model. IFAC-PapersOnLine, 52(13), 838-843. https://doi.org/10.1016/j.ifacol.2019.11.234

Indiani, N. L. P., Rahyuda, I. K., Kerti Yasa, N. N., \& Sukaatmadja, I. P. G. (2015). Perceived risk and trust as major determinants of actual purchase, transcending the influence of intention. ASEAN Marketing Journal, 7(1), 1-13. https://doi.org/10.21002/amj.v7i1.4601

Jambulingam, M. (2013). Behavioural intention to adopt mobile technology among tertiary students. World Applied Sciences Journal, 22(9), 1262-1271. https://doi.org/10.5829/idosi.wasj.2013.22.09.2748

Jewer, J. (2018). Patients' intention to use online postings of ED wait times: A modified UTAUT model. International Journal of Medical Informatics, 112, 34-39. https://doi.org/10.1016/j.ijmedinf.2018.01.008

Kabra, G., Ramesh, A., Akhtar, P., \& Dash, M. K. (2017). Understanding behavioural intention to use information technology: Insights from humanitarian practitioners. Telematics and Informatics, 34(7), 1250-1261. https://doi.org/10.1016/j.tele.2017.05.010

Kapferer, J. N., Klippert, C., \& Leproux, L. (2014). Does luxury have a minimum price? An exploratory study into consumers' psychology of luxury prices. Journal of Revenue and Pricing Management, 13(1), 2-11. https://doi.org/10.1057/rpm.2013.34

Khechine, H., Raymond, B., \& Augier, M. (2020). The adoption of a social learning system: 
Understanding online shopping adoption: The unified theory of acceptance and the use of technology in millennial consumers context and perceived risk application by Rian Piarna, Ferdi Fathurohman, Nunu Nugraha

Intrinsic value in the UTAUT model. British Journal of Educational Technology. https://doi.org/https://doi.org/10.1111/bjet.12905

Kim, C. F., \& Zhang, L. (2016). Corporate political connections and tax aggressiveness. Contemporary Accounting Research, 33(1), 78-114. https://doi.org/10.1111/19113846.12150

Lestari, D. (2019). Measuring e-commerce adoption behaviour among gen-Z in Jakarta, Indonesia. Economic Analysis and Policy, 64, 103-115. https://doi.org/10.1016/j.eap.2019.08.004

Liu, L., Miguel Cruz, A., \& Juzwishin, D. (2018). Caregivers as a proxy for responses of dementia clients in a GPS technology acceptance study. Behaviour \& Information Technology, 37(6), 634-645. https://doi.org/10.1080/0144929X.2018.1470672

Madigan, R., Louw, T., Dziennus, M., Graindorge, T., Ortega, E., Graindorge, M., \& Merat, N. (2016). Acceptance of automated road transport systems (ARTS): An adaptation of the utaut model. Transportation Research Procedia, 14, 2217-2226. https://doi.org/10.1016/j.trpro.2016.05.237

Narasuman, S., Yunus, M., Md, R., \& Kamal, A. A. (2011). Net generation student teachers: how tech-savvy are they?. Journal of Educators \& Education/Jurnal Pendidik Dan Pendidikan, 26(1), 71-89. Retrieved from https://core.ac.uk/reader/83543475

Octarina, E., Hartoyo, H., \& Beik, I. S. (2019). Customer purchase intention on sharia mutual fund products: A TPB approach. Journal of Consumer Sciences, 4(1), 37. https://doi.org/10.29244/jcs.4.1.37-47

Octaviani, E. S., \& Gunawan, H. (2018). Perceived risk on consumer online shopping behaviour, 3(2), 203-209. https://doi.org/https://doi.org/10.30871/jaat.v3i2.876

Ouellette, J. A., \& Wood, W. (1998). Habit and intention in everyday life: The multiple processes by which past behavior predicts future behavior. Psychological Bulletin, 124(1), 54-74. https://doi.org/10.1037/0033-2909.124.1.54

Pham, M., Valette-Florence, P., \& Vigneron, F. (2018). Luxury brand desirability and fashion equity: The joint moderating effect on consumers' commitment toward luxury brands. Psychology and Marketing, 35(12), 902-912. https://doi.org/10.1002/mar.21143

Primanto, A. B., ABS, M. K., \& Slamet, A. R. (2018). A study of the best selling smartphone 
in the two biggest marketplace in Indonesia. Jurnal Terapan Manajemen Dan Bisnis, 4(1), 17-24. https://doi.org/10.26737/jtmb.v4i1.487

Primanto, A. B., \& Dharmmesta, B. S. (2019). What happens after they laugh: How humorous advertisements have an effect on consumers' attitudes, word of mouth intentions, and purchase intentions, with the need for humor playing a moderating role. Journal of Indonesian Economy and Business, 34(2), 117. https://doi.org/10.22146/jieb.23036

Sahu, G. P., \& Singh, M. (2017). Factors influencing consumer's behavioral intention to adopt irctc connect mobile application. In Lecture Notes in Computer Science (including subseries Lecture Notes in Artificial Intelligence and Lecture Notes in Bioinformatics) (pp. 3-15). https://doi.org/10.1007/978-3-319-68557-1_1

Salam, A. F., Rao, H. R., \& Pegels, C. C. (2003). Consumer-perceived risk in e-commerce transactions. Communications of the ACM, 46(12), 325. https://doi.org/10.1145/953460.953517

Siddique, M. A. M. (2012). Explaining the role of perceived risk, knowledge, price, and cost in dry fish consumption within the theory of planned behavior. Journal of Global Marketing, 25(4), 181-201. https://doi.org/10.1080/08911762.2012.743203

Somba, W. E., Sunaryo, S., \& Mugiono, M. (2018). Pengaruh nilai hedonis dan nilai utilitarian terhadap behavioral intention, dengan word of mouth (WOM) sebagai variabel mediasi. Jurnal Manajemen Dan Kewirausahaan, 6(1), 82. https://doi.org/10.26905/jmdk.v6i1.2071

Tak, P., \& Panwar, S. (2017). Using UTAUT 2 model to predict mobile app based shopping: evidences from India. Journal of Indian Business Research, 9(3), 248-264. https://doi.org/10.1108/JIBR-11-2016-0132

Tarhini, A., El-Masri, M., Ali, M., \& Serrano, A. (2016). Extending the UTAUT model to understand the customers' acceptance and use of internet banking in Lebanon. Information Technology \& People, 29(4), 830-849. https://doi.org/10.1108/ITP-022014-0034

Tingchi Liu, M., Brock, J. L., Cheng Shi, G., Chu, R., \& Tseng, T. (2013). Perceived benefits, perceived risk, and trust. Asia Pacific Journal of Marketing and Logistics, 25(2), 225-248. https://doi.org/10.1108/13555851311314031 
Understanding online shopping adoption: The unified theory of acceptance and the use of technology in millennial consumers context and perceived risk application by Rian Piarna, Ferdi Fathurohman, Nunu Nugraha

Venkatesh, V., Morris, M. G., Davis, G. B., \& Davis, F. D. (2003). User acceptance of information technology: Toward a unified view. MIS Quarterly: Management Information Systems, 27(3), 425-478. https://doi.org/10.2307/30036540

Venkatesh, V., Thong, J. Y. L., \& Xu, X. (2012). Consumer acceptance and use of information technology: Extending the unified theory of acceptance and use of technology. MIS Quarterly: Management Information Systems, 36(1), 157-178. https://doi.org/10.2307/41410412

Wang, Y., \& Herrando, C. (2019). Does privacy assurance on social commerce sites matter to millennials? International Journal of Information Management, 44, 164-177. https://doi.org/10.1016/j.ijinfomgt.2018.10.016

Warkentin, M., Gefen, D., Pavlou, P. A., \& Rose, G. M. (2002). Encouraging citizen adoption of e-government by building trust. Electronic Markets, 12(3), 157-162. https://doi.org/10.1080/101967802320245929

Wong, S.-M., Leong, C.-M., \& Puah, C.-H. (2020). Mobile internet adoption in malaysian suburbs: The moderating effect of gender. Asian Journal of Business Research, 9(3). https://doi.org/10.14707/ajbr.190069

Yu, T. W., \& Chen, T. J. (2018). Online travel insurance purchase intention: A transaction cost perspective. Journal of Travel and Tourism Marketing, 35(9), 1175-1186. https://doi.org/10.1080/10548408.2018.1486781

Zuiderwijk, A., Janssen, M., \& Dwivedi, Y. K. (2015). Acceptance and use predictors of open data technologies: Drawing upon the unified theory of acceptance and use of technology. Government Information Quarterly, 32(4), 429-440. https://doi.org/10.1016/j.giq.2015.09.005

Zulfikar, R., \& Mayvita, P. A. (2018). The relationship of perceived value, perceived risk, and level of trust towards green products of fast moving consumer goods purchase intention. JEMA: Jurnal Ilmiah Bidang Akuntansi Dan Manajemen, 15(2), 85-97. https://doi.org/10.31106/jema.v15i2.838 


\section{Appendix 1a. Questionnaire Items}

\begin{tabular}{|c|c|c|}
\hline Variable & Code & Item \\
\hline \multirow{3}{*}{$\begin{array}{l}\text { Performance } \\
\text { Expectancy }\end{array}$} & PE1 & Using Internet for online shopping useful in my daily life. \\
\hline & PE2 & Using the internet to shop online helps me buy products faster \\
\hline & PE3 & Using the internet to shop online increases my productivity \\
\hline \multirow{3}{*}{$\begin{array}{l}\text { Effort } \\
\text { Expectancy }\end{array}$} & EE1 & Online shopping is easy to learn \\
\hline & EE2 & The interaction process of online shopping is easy to understand \\
\hline & EE3 & It is easy for me to use the internet to online shopping \\
\hline \multirow{3}{*}{$\begin{array}{l}\text { Social } \\
\text { Influence }\end{array}$} & SI1 & My best friend recommended to me to shop via internet/online \\
\hline & $\mathrm{SI} 2$ & My neighbourhood recommended to me to shop via internet/online. \\
\hline & $\mathrm{SI} 3$ & My peers recommended to me to shop via internet/online \\
\hline \multirow{3}{*}{$\begin{array}{l}\text { Facilitating } \\
\text { Condition }\end{array}$} & $\mathrm{FC} 1$ & I do have resources which required to online shopping \\
\hline & $\mathrm{FC} 2$ & I have enough knowledge to use the internet in online shopping \\
\hline & FC3 & I have a friend or group who is willing to help with online shopping \\
\hline \multirow{3}{*}{$\begin{array}{l}\text { Hedonic } \\
\text { Motivation }\end{array}$} & HM1 & Using the internet for shopping gives me pleasure \\
\hline & HM2 & Using the internet for shopping really entertained me \\
\hline & HM3 & I enjoy shopping using the internet \\
\hline \multirow{3}{*}{ Price Value } & PV1 & I think the cost in using the internet for online shopping is affordable \\
\hline & PV2 & I think the cost in using the internet for online shopping is reasonable \\
\hline & PV3 & $\begin{array}{l}\text { The costs I incurred to use the internet in shopping are comparable } \\
\text { with the benefits that I get }\end{array}$ \\
\hline \multirow{3}{*}{ Habit } & H1 & Using the internet to shop online has become a habit for me \\
\hline & $\mathrm{H} 2$ & Using the internet to shop online has become a necessity for me \\
\hline & $\mathrm{H} 3$ & If I want a product, I will use the internet for online shopping \\
\hline \multirow{3}{*}{$\begin{array}{l}\text { Perceived } \\
\text { Risk }\end{array}$} & PR1 & Using Internet for shopping is potential fraud. \\
\hline & PR2 & Using Internet for shopping is financial risk. \\
\hline & PR3 & I think using Internet for shopping puts my privacy at risk. \\
\hline \multirow{3}{*}{$\begin{array}{l}\text { Performance } \\
\text { Risk }\end{array}$} & PFMR1 & There would be possibility of system errors when shopping online \\
\hline & PFMR2 & The security system of shopping websites still has weaknesses \\
\hline & PFMR3 & $\begin{array}{l}\text { Instability of internet performance could damage my online shopping } \\
\text { experience }\end{array}$ \\
\hline
\end{tabular}


Understanding online shopping adoption: The unified theory of acceptance and the use of technology in millennial consumers context and perceived risk application by Rian Piarna, Ferdi Fathurohman, Nunu Nugraha

\section{Appendix 1b. Questionnaire Items}

\begin{tabular}{lcl}
\hline Variable & Code & \\
\hline Financial & FR1 & Using the internet to online shopping, is potentially fraudulent \\
Risk & FR2 & Using the internet to online shopping, results in financial losses \\
Privacy & PVR1 & It would be risky to give personal information to shopping website \\
Risk & PVR2 & Personal identity could be inappropriately used by shopping website \\
& PVR3 & There would be high potential for privacy loss when shopping online \\
Behavioural & BI2 & I want to use the internet in shopping activities regularly \\
Intention & BI3 & I wish to online shopping in my daily life \\
& BI4 & I plan to continue to use the internet to shop continuously \\
& UB1 & I often use the internet to online shopping \\
Use & UB2 & Whenever I want to shop, I used the internet to online shopping \\
Behaviour & UB3 & I always use the internet to online shopping anywhere \\
\hline
\end{tabular}

